\title{
REVEALING GUERNSEY'S ANCIENT HISTORY IN FACT AND FICTION
}

\author{
[Received January 25th 2016; accepted June 22nd 2016 - DOI: 10.21463/shima.10.2.12] \\ Peter Goodall \\ University of Southern Queensland <peter.goodall@gmail.com>
}

\begin{abstract}
In G. B. Edwards' novel of 2oth Century Guernsey life, The Book of Ebenezer Le Page (1981), Ebenezer becomes the unlikely custodian of an 'ancient monument' discovered on his land. The incident is treated, in the main, as a topic for comedy-a part of the novel's satire of the many pretences and frauds of modern Guernsey-but the underlying issues should not be lightly put aside. 'Les Fouaillages', a megalithic site discovered in 1978, the year after Edwards's death, on L'Ancresse Common, a short walk from the place where the fictional Ebenezer spent his whole life, is thought to be 6000 years old, and has a claim to be amongst the oldest built sites on the planet. There are many other ancient sites and monuments on this small island, as there are on the neighbouring Channel Island of Jersey. This article looks at the interconnected yet contrasting ways in which this extraordinary legacy on Guernsey has been revealed and described: the scholarly discourse of archaeology, the myth and legend of the popular imagination, and the literature of Guernsey's poets and novelists.
\end{abstract}

KEYWORDS: Guernsey; Neolithic Age; megaliths; G. B. Edwards; Victor Hugo.

All over Europe, especially western Europe, can be found the remains of what we now call 'Neolithic', or New Stone Age, culture, a period that in European history stretched from (roughly) $7000 \mathrm{BC}$ to (roughly) $2000 \mathrm{BC}$, depending upon location. It is distinguished in material terms by a transition from a nomadic to a settled farming lifestyle, the cultivation of cereals and the domestication of animals, and the use of polished or ground stone for tools, in contrast to the flaked stone tools of the 'Palaeolithic' (the Old Stone Age). In cultural terms, one of the most visible manifestations of the New Stone Age was the use of massive stones (megaliths) in ritual structures of one kind and another: stone circles; dolmens or cromlechs (structures consisting of two or more large stones capped by another flat stone and covered over with earth); passage graves; menhirs (single standing stones); and, perhaps most spectacularly of all, in full temples, such as the site of Ggantija on Gozo, Malta, which has been dated as early as 3750 BC. Although many of these sites can be found inland, such as south-west England or in Brittany, a surprising number are located on islands, sometimes in what are now remote places. Some of the most impressive stone circles in the British Isles, for example, as well as some of the strongest witnesses of the everyday life of Stone-Age people, are to be found in the Orkney Islands off the north coast of Scotland.

Although they do not rival those on Gozo, the Neolithic sites of Guernsey, one of the islands in the English Channel, are still impressive, and an unusually large proportion of them take the form of megalithic monuments. As Paul Patton has pointed out, this is characteristic of the Neolithic sites of the Armorican area as a whole, but it is especially 


\section{Goodall: Revealing Guernsey's Ancient History}

true of the Channel Islands. Of 126 sites that he mentions, 79 (63\%) are megalithic monuments and only 10 (8\%) are settlements (Patton, 1995: 8). Examples of the most notable include the statue-menhir that stands just outside the parish church of St Martin, known popularly as 'La Gran'mère du Chimquière' (the grandmother of the cemetery), which is dated c. 2000 BC (Figure 1); the passage grave of Le Déhus, dated to as early as 4000 BC by recent AMS (accelerator mass spectronomy) studies (Jelly, 2016: loc.3223) (Figure 2); and Les Fouaillages (Figure 3).

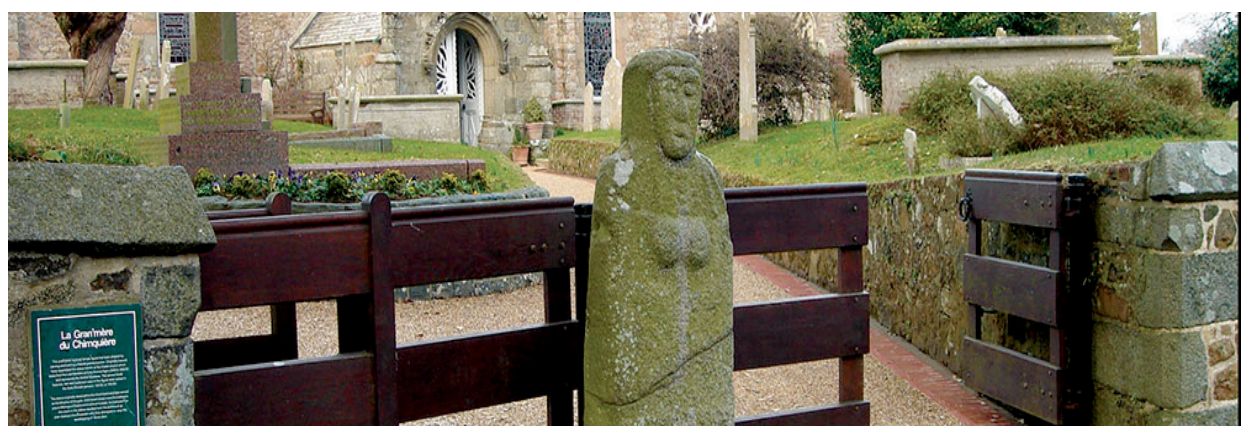

Figure 1 - La Gran'mère du Chimquière (author's photograph 2010)

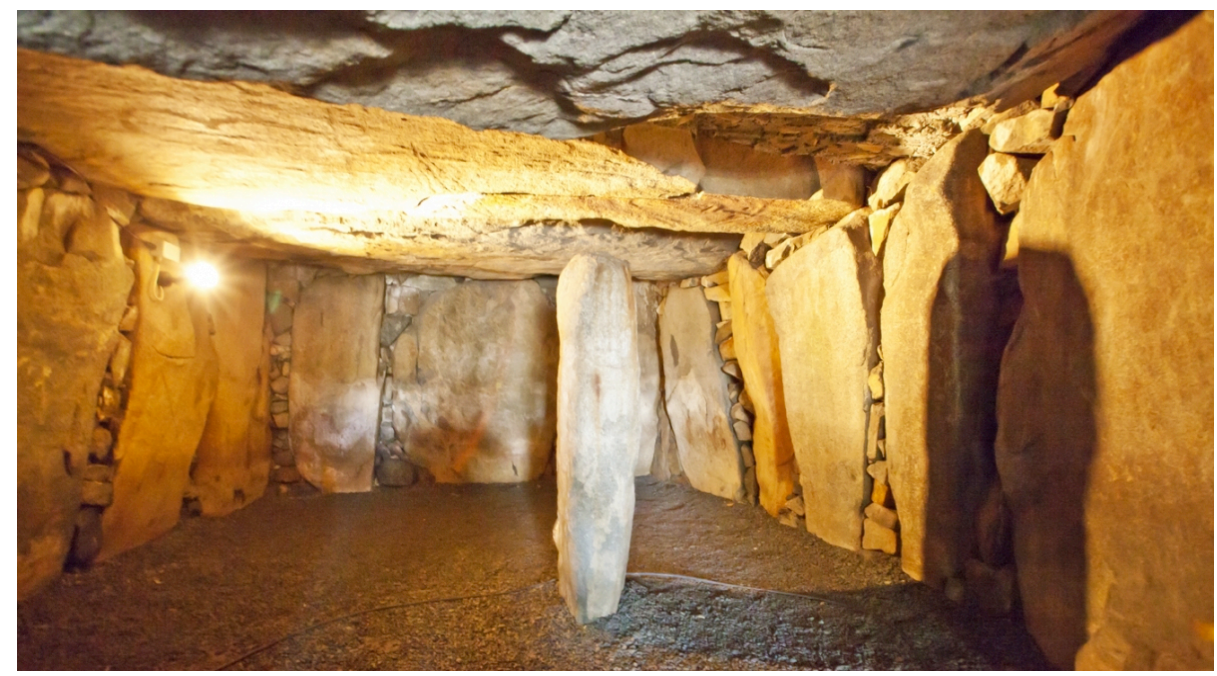

Figure 2 - The passage grave at Le Déhus, photograph by Unukorno

(https://commons.wikimedia.org/wiki/File:Guernsey_Le_Dehus.jpg, reproduced without change under the Creative Commons Attribution-Share Alike 3.o Unported license) 


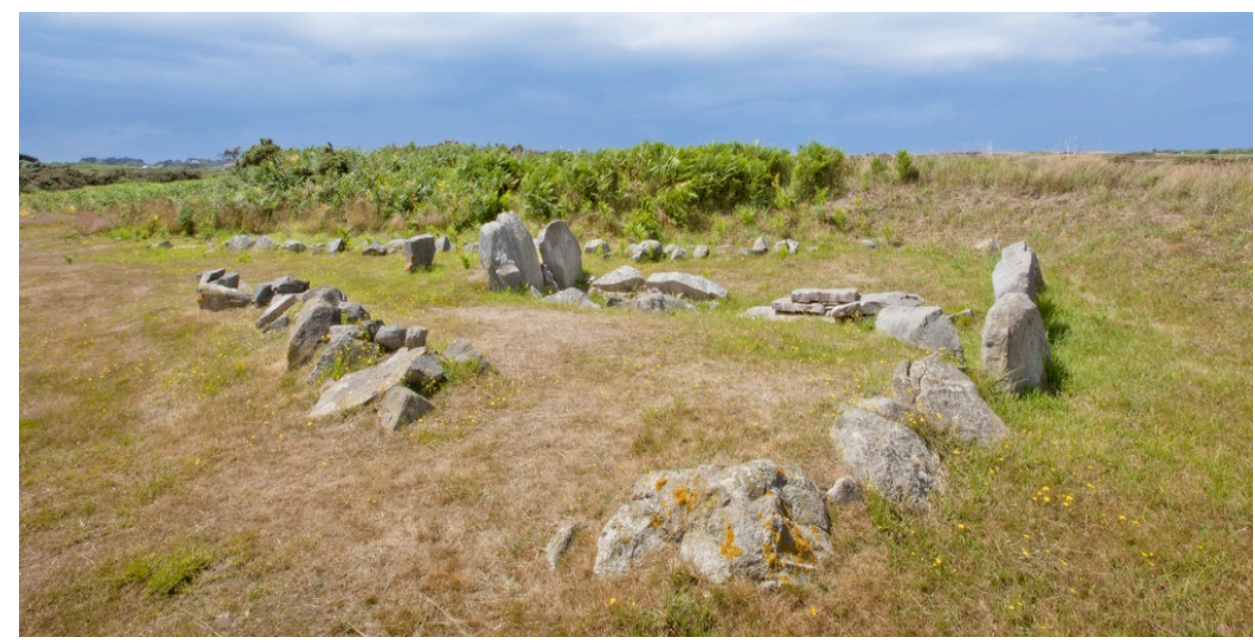

Figure 3 - Les Fouaillages (image courtesy of VisitGuernsey, http://www.visitguernsey.com)

This last site, one of the very oldest, can be found on L'Ancresse Common in the far north of the island, an area mentioned in both the literary works I shall discuss. When Ian Kinnes of the British Museum excavated the site in the late 1970s, he found a scatter of flint tools alongside the site that could be dated to the late Mesolithic (Middle Stone Age) (Kinnes, 1982: 26). According to Kevin Jelly, these flint tools can be dated to 5500 BC, and the tomb proper is notably old, datable to 4500 BC (Jelly, 2016: loc. 3223). Overall, David E. Johnson has said that the Channel Islands offer "a display of monuments whose preservation is unmatched in most parts of Europe today" (Johnson, 1981: xi). Even so, what we can see today is much less than what existed in the past-such has been the effect of theft, destruction for religious reasons, and both official and unofficial quarrying of building materials. J. L. Hibbs has described the current situation as "the eroded remains of a far denser and more complex ritual landscape” (Hibbs, 1986: 209).

In the popular imagination, the megaliths were always objects of ignorance and superstition, linked to paganism, devil worship and magic. Many of the Guernsey sites bear names that are suggestive of these associations, for example 'Le Creux ès Faïes' [The Fairies' Cave] on the L'Eree headland. Some sites were especially associated with black magic. 'Le Trepied' at Catioroc "figured largely in the witchcraft trials of the postReformation period. According to the confessions extracted under torture from some of them, the devil, in the shape of a black goat, called Baal-Barth or Barbarie, sat on the central capstone of the dolmen whilst his adherents danced around in ritual worship, chanting his praises" (De Garis, 1975: 234-35). Local people remained convinced of the magical associations of the stones into recent times (Sunbright57, 2012). They have also been a fertile element in the cultural imaginary of the island evoked in literature as well. Both the prehistoric remains of the island and its folklore steeped in the supernatural inspired the Guernsey poet, George Métivier (1790-1881). Meetings with devils and bewitchments are some of the favourite themes in the poems he wrote in GuernseyFrench. One poem, 'La Maison Ensorchellaie' [The Haunted House], written in the early decades of the 19th Century, features a devil that has come from Le Catioroc itself: 


\title{
Goodall: Revealing Guernsey's Ancient History
}

\author{
J'ai veue su san gnêt, éperquie \\ Derriere le ner tout en travers \\ Tu sai bien qui.... all est partie \\ Au Cakiau Ro... ou en enfer. \\ I saw astride her broom, \\ Behind Old Nick, the old so-and-so \\ You know very well who... and off she went \\ To Le Catioroc... or to hell. (Jennings and Marquis, 2011: 279-80, 283)
}

Métivier's evocation of the popular imagination of the island in its own language was, however, an aspect of the scholarly antiquarianism that drove him to compile a dictionary of Guernsey-French as well. He also corresponded throughout his life with the pioneers of archaeology on the island. One of his early publications was a paper, read to the Bristol Literary Society in 1827, on the 'Cromlechs, Barrows and Danish Entrenchments of Guernsey' (Lenfestey, 2011: 704).

Before the development of archaeology in the 19th Century and accurate dating methods in the 2oth, the major obstacle to a scientific understanding of the remote past was a total misunderstanding of the true age of the planet, the human race, and its cultures. Someone writing in Britain, for example, could see evidence and assign reliable dates to the culture of the Romans: material traces of their existence were all around and the Romans had themselves written and dated the events of their lives. Societies that existed before that time could also be imagined and in some cases seen because the Romans had written about them as well even if those cultures themselves did not. What existed before that, however, could hardly be imagined at all, and there cannot have been much of it anyway, given that the chronology of the world based upon a literal reading of the Bible advanced by James Ussher (1581-1656), created by God on 23 October 4004 BC, was widely accepted. Philip Falle (1656-1742), for example, a native of the neighbouring island of Jersey, begins the history chapter of his survey of Jersey, first published in 1697, with the Romans. He acknowledges a Celtic people, the 'Gauls', including their priestly caste called 'Druids', who fought against the Romans; they are the "Aborigines of the country, forasmuch as no history goes beyond them" (Falle, 1734: 7). Accordingly, he saw the megaliths as "Old Monuments of Paganism", manifestations of the "Superstition of the Druids... and are the altars whereon Sacrifices were offered by them, not of Beasts only, but of Living Men also" (Falle, 1734: 256-57). This largely derives from a tradition established by John Aubrey (1626-1697), of course, who had first advanced the theory that Stonehenge was the work of Druids in his survey of 1649 . His ideas were extended, systematised and popularised by William Stukeley (1687-1765) in his Stonehenge: a Temple Restor'd to the British Druids (1740). Thereafter, this view obtained widely for the next century, until the 1850 os, when it was challenged from a number of directions.

A crucial aspect to the challenge was the growing understanding of the true age of the planet. One of the underlying influences in this was the work of the geologist, Charles Lyell (1797-1875). From the 1830 se argued not only for the great antiquity of the Earth, but also that its slow transformation has been the result of natural process rather than catastrophe, such as Noah's Flood. For example, we can see how the processes of erosion and sedimentation change the nature of the landscape, but we also know from observation how long it takes to effect small changes; from that we can infer the length of time it would take to flatten the mountains into hills and plains and for rivers to sculpt valleys. Without any more precise means of dating, Lyell's thoughts began to transcend common, 
measurable time. In a famous line, he slightly misquotes the $18^{\text {th }}$ Century geologist, James Hutton (1726-1797), in saying of the Earth: "I can find no traces of a beginning, no prospect of an end" (Lyell, 1997: 16).

The 'Druid thesis' of megalithic remains was finally and comprehensively challenged by Sir John Lubbock's Prehistoric Times, published in 1865. In the introductory comments to the book, Lubbock (1834-1913) makes the point that "man's" existence in Europe "dates from a period so remote, that neither history, nor even tradition, can throw any light on his origin, or mode of life" (Lubbock, 1890: 1). Instead, he believed that the development of the new science of archaeology, which linked geology and history, would enable greater understanding, and his book contains extensive description and analysis of artefacts of all types. He built upon the 'Three Age' theory of the Danish archaeologist Christian Jürgensen Thomsen (1788-1865), formulated in the 1820s-although in some ways it is as old as Lucretius-, in which human civilisation could be divided successively into Stone, Bronze, and Iron Ages. Lubbock refined this system, particularly in his description of the Stone Age, which he sub-divided and identified by two new terms that he coined for them: the 'Palaeolithic' or Old Stone Age and the 'Neolithic' or New Stone Age. By the 1870s, Lubbock's systematisation of the history of the ancient world was widely accepted, as was his unlinking of the connection between the megaliths and the Celtic world of the Druids: although "in this country we still habitually call the megalithic monuments 'Druidical'... it is hardly necessary to mention that there is really no sufficient reason for connecting them with Druidical worship" (Lubbock, 1890: 123). It is, however, still worth pointing out how few 'dates' there are in his book; until the development of radio-carbon dating in the 2oth Century, the centuries and millennia of the Stone Ages could only be foggily grasped. Furthermore, although Lubbock rejected the connection between megalithic remains and Druid worship, he still believed, however, that remains such as stone circles belonged to a period after the Stone Age.

The year of publication of Lubbock's book has an interesting congruence with the first literary treatment of the megaliths that I want to look at: Victor Hugo's (1802-1885) great novel of Guernsey life, Les Travailleurs de la mer (Toilers of the Sea), published in 1866. In fact, considerable archaeological work had been undertaken in the Channel Islands themselves during the previous two decades, focussing especially on the megaliths. Much of it was carried out by the Lukis family, especially Frederick Corbin Lukis (1788-1871) and his son Frederick Collings Lukis (1817-1892). Although the elder Lukis was self-taught, he had polymathic interests and significant international connections to other archaeologists. As early as 1848 , he was one of the first scholars to realise that the stone dolmens and cromlechs of Guernsey were tombs and not Druidic sacrificial altars (Johnson, 1981: 56). The Lukis family were early 'rescue archaeologists' as well, not only describing but occasionally purchasing sites themselves one step ahead of the quarryman's hammer-a constant threat when the quarrying of granite was the island's principal industryalthough more recent archaeologists have cautioned that "their recording, and often their inaccurate replacement of stones in disturbed monuments, have often confused the evidence" (Hibbs, 1986: 220). More detailed understanding of the sites was furthered by the Oliver Report of 1873 , commissioned by the Ethnological Society of London, into the state of prehistoric monuments on the islands. At the same time, learned societies with compatible aims were founded in both Guernsey and Jersey: La Société Jersiaise in 1876 and La Société Guernesiaise in 1882; the Transactions of the latter was first published in 1893 (Johnson, 1981: 56-7). 
Although published in 1866, the events of the novel are set in the different world of the 1820s, in the middle of what Ronald Hutton has called the "high summer of Druidry in the English and Welsh imagination" (Hutton, 2007: 61). Hugo's novel enacts a struggle between superstition and scientific understanding that mirrors the debates of the time, although it's not always described in the same terms. The opening pages of the novel depict the Guernsey of the early 19th Century as a place of profound ignorance: "The Vale and St Sampson were, fifty years ago, places remarkable for the ignorance of their inhabitants" (Hugo, 1911: 19). Some of this was the result of the pervasive sectarianism of the island, overwhelmingly Protestant (Calvinist) even though saturated in French culture in so many other ways, but with the Protestant denomination itself divided between Church and Chapel: "Small as is the island of Guernsey, it has, unfortunately, plenty of room for differences of religion... every form of worship has its temple or chapel" (Hugo, 1911: 62). But outside the town especially, the true faith is magic: "in the country, the more the doctor is suspected of magic, the more certain is his cure" (Hugo, 1911: 19). Locations with powerful associations of magic and paganism are very important in the novel: a haunted house at Pleinmont, an area notorious for witchcraft in works beyond Hugo's; old St Malo on the Breton coast, where "tumbledown houses and sorcerers always go together" (Hugo, 1911: 108). One of the reasons for the islanders' deep suspicion of Gilliatt, the novel's reclusive protagonist, is that he doesn't attend either Church or Chapel. Prominent among Gilliatt's other eccentricities, linked clearly in the minds of the islanders with consorting with sorcerers, is visiting the megalithic sites of the island, in particular those near L'Ancresse Common:

He never went to chapel. He often went out at night-time. He held converse with sorcerers. He had been seen on one occasion sitting on the grass with an expression of astonishment on his features. He haunted the Druidical stones of the Ancresse, and the fairy caverns which are scattered about in that part... He bought all birds which people brought to him, and having bought them, set them at liberty. (10)

At first glance, Hugo seems simply to have blended the romantic topos of the outcast with the contemporary view of the stones' magical associations, but, in fact, what lies behind Gilliatt's reverie is not sorcery but its opposite, a curiosity and wonder at the natural world that is the foundation of science: "[Gilliatt] was a dreamer, nothing more" (Hugo, 1911: 25). Or, to put it another way, again linking wonderment with science: "[he] was a kind of seer amid the secrets of nature" (Hugo, 1911: 223). Likewise, his successes as seaman and fisherman, winning him in the early part of the story the boat that is used so effectively later on, is the result of observation and knowledge rather than spells and demonology.

This emerges most in the great task that he undertakes, which occupies the largest part of the novel. Another man of science, Mess Lethierry-who, it should be added, has an aversion to priests in the way that a dog hates cats-has built and operates the first steamship to be in commercial use in the islands. It has cut the length of journeys to France and to England in half, made passage more certain and less dependent on the weather, but the ship, named the "Durande", is instead seen by the islanders as the work of the devil, with its noise, smell and smoke. For a local preacher it is "Leviathan", and it is reviled as a "Devil Boat" by "worthy fishermen, once Catholics, now Calvinists, but always bigots" (Hugo, 1911: 40). The Durande is launched on 14 July, and Lethierry picks up the revolutionary significance of the date: "It's your turn now! The Parisians took the Bastille, now science takes the sea”' (Hugo, 1911: 49). 
As a consequence of a fraud perpetrated by the ship's captain that goes amiss, the Durande is wrecked on the Roches Douvres, a notorious reef in the Channel, coming to rest wedged between two granite pillars. Although most of the hull is shattered, the engine and funnel are, remarkably, intact and salvageable as long as the rest of the ship doesn't disintegrate. Facing ruin, Mess Lethierry begs for someone to attempt the recovery of the ship's engine, and, in a moment of despair, his beautiful niece, Déruchette, offers to marry the man who can bring back the engine to Guernsey. Previously, he had granted his niece the right to marry whomever she pleased, "provided you do not marry a parson" (Hugo, 1911: 65). Gilliatt, supremely skilled and practical as he is, but unworldly in so many other ways, offers to go. In the middle chapters of the book, his remarkable feat of salvage is detailed.

Although Gilliattt proves himself a hero of rationalism and scientific understanding, there are countervailing forces at work here as well. The position of the wreck reminds Gilliatt of nothing so much as one of the dolmens of the island. Hugo illustrated his own novels, but the metaphor is better captured by a slightly later illustration by François Flameng:

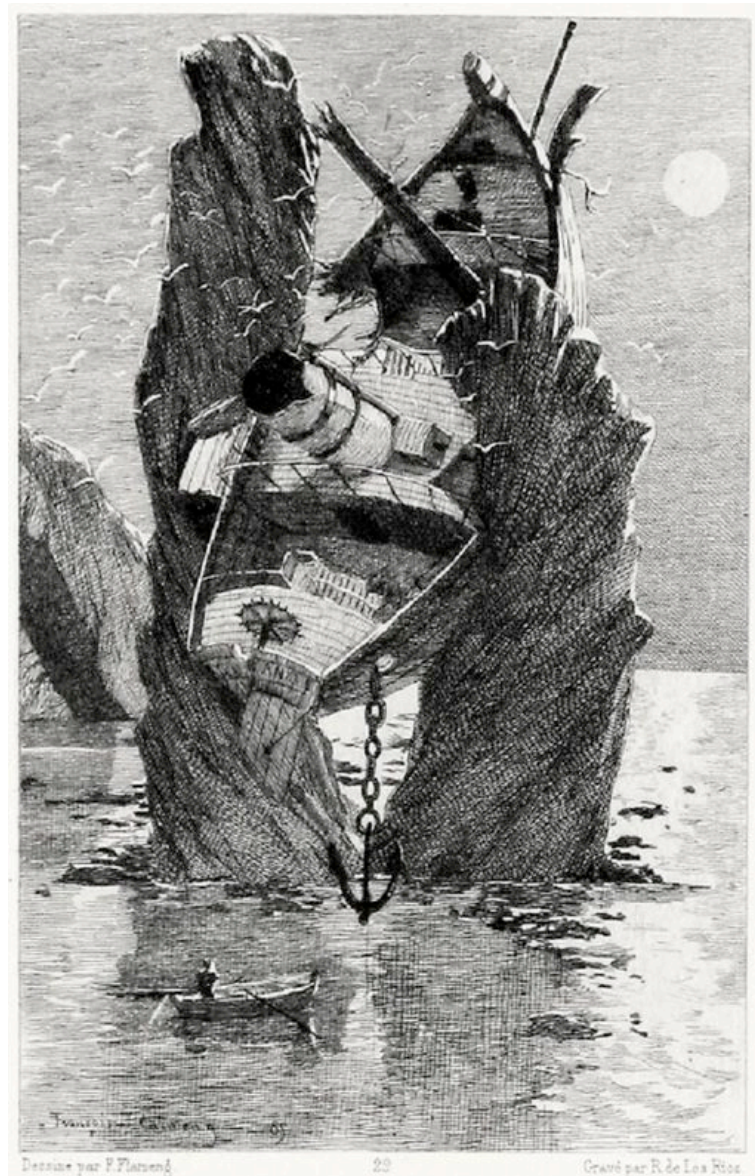

Figure 4 - The wreck of The Durande (Flameng, 1885)

The great feats of seamanship and engineering performed by Gilliatt are a kind of victory of science over ignorance and superstition. When Gilliatt returns to Guernsey, Mess 


\section{Goodall: Revealing Guernsey’s Ancient History}

Lethierry is overwhelmed by his skill and efforts but he is also full of warnings of how this will be misunderstood by the islanders:

Why, they would have burnt you a hundred years ago. It is magic! There isn't a screw missing... Why you must have gone down to the infernal regions... All the powers of darkness were against you...It's true that you are a magician. $(335,337,340)$

There are other ironies at work here besides Gilliatt's efforts somehow proving that he is a magician after all. Mess Lethierry is more than willing to offer his niece to Gilliatt as a bride, but Déruchette herself is mortified. Although her uncle knows nothing of it, she has already fallen in love with another man, Ebenezer Caudray-worse than that, he is the local parson. When Gilliatt finds this out, he resigns all claims on Déruchette; in fact, he organises her elopement with the young clergyman, and the last tragic pages of the novel show Gilliatt sitting among the rocks on the sea shore, gazing out on the departing ship as he patiently awaits his own death by drowning from the incoming tide.

By the time of G. B. Edwards' (1899-1976) novel of Guernsey life-published posthumously in 1981 and dealing with events on the island over a period roughly from the late 1880 os to the late 1960s-much had changed in the understanding of the island's megaliths. Johnson describes these decades before and after the First World War as a Golden Age of archaeology in the Channel Islands (Johnson, 1981: 57). Some of this is likely to have been due to the personal influence of Robert Ranulph Marett (1866-1943), a distinguished academic who was also a member of one of Jersey's most ancient and influential families, the "seigneurs du Franc Fief en St Brelade" (Marett, 1941: 234), who were in their turn connected through marriage with most of the other great families of the island. His father, Robert Pipon Marett (1820-1884), had become Bailiff of Jersey-effectively its Head of Government-in 1880, and, amongst other of his literary interests and achievements, he was one of the founders of La Société Jersiaise and wrote poetry in the patois of the island. Fellow and later Rector of Exeter College, Oxford, R. R. Marett's academic background was in Classics and Philosophy, but he became an important figure in the development of Anthropology at Oxford, appointed Reader in Anthropology in 1910 and establishing the University's first Department of Social Anthropology in 1914. His primary interest was in the development of religious consciousness, but he returned to Jersey during the summer months each year and led the excavation of the Lower Palaeolithic site of La Cotte [cave] de St Brelade from 1910-1914. This site provides the "earliest evidence for human occupation" in the Channel Islands (Patton, 1995: 1). Elsewhere on the island of Jersey, the most remarkable of all Neolithic sites in the Channel Islands was excavated at La Hougue Bie, a large burial mound, and its "spectacular chambered tomb" (Johnson, 1981: 57), approached by a passage 9.7 metres long, was revealed in 1924. The mound is 12 metres high and 55 metres in circumference and bears the weight of a conjoined pair of medieval chapels, one built in the 12th and the other in the 16th centuries (Johnson, 1981: 65). On Guernsey, work of equal importance was done in these years and a number of major sites were excavated. The Reverend G. E. Lee and Major S. Carey Curtis were associated with several excavations: two of the most prominent took place at L'Islet in 1912, and at Le Déhus, called by Johnson "one of the finest passage-graves in north-western Europe" (103), in 1919. This work by a number of archaeologists, amateur and professional, culminated in the publication in 1928 of the first volume of T. D. Kendrick's The Archaeology of the Channel Islands, concerned with Guernsey, followed by a second volume on Jersey by Jacquetta Hawkes, one of the most celebrated archaeologists of the time, in 1939. 
The involvement of the book's fictional narrator, Ebenezer le Page, with some prehistoric remains takes place in episodes over several years, initially at an unspecified time, but which we may infer begins in the 1930s. Some years before, Ebenezer's uncle Percy had built a wall on Ebenezer's property and had placed some chipped stones that were lying around on the top of it for ornament. An English academic, Dudley Waine (with an 'e' as he pedantically insists), who comes to Guernsey each summer-a practice reminiscent of the real life Marett's on Jersey-and boards with Percy and his wife, notices these with great excitement. Dudley is a bit of a caricature: fussy, slightly effeminate, prone to sudden enthusiasms, but also selfish and self-serving. He concludes immediately that these are Stone Age axe-heads. It's never entirely clear from the novel whether this may be so or whether the chipping has been done by Uncle Percy himself.

The next year Dudley discovers a trough in Ebenezer's pig-sty, which looks to him very much like part of an "ancient barrow of the Old Stone Age" (Edwards 1981: 197). Notice the inflation in the age of the finds: the trough belongs to the Old Stone Age according to Dudley-one of the rivalries between Guernsey archaeologists and Jersey archaeologists in the period was over the presence of Old Stone Age (Palaeolithic) remains on Jersey while Guernsey could only muster evidence from the New Stone Age (the Neolithic). Another season, after a violent rain storm has washed away part of Ebenezer's garden, a number of standing stones similar in size and shape to the pig trough are revealed in a pattern that looks similar to those revealed at L'Islet, excavated in 1912 (Figure 5).

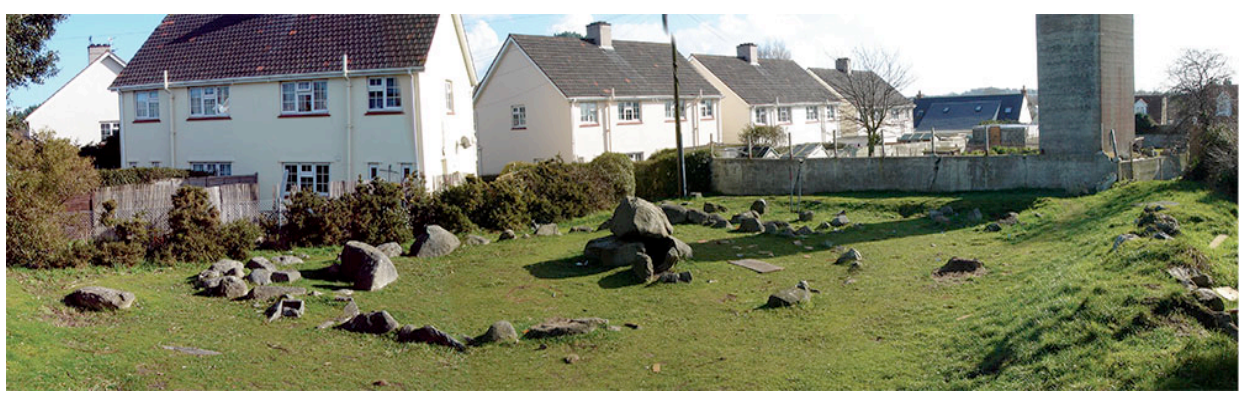

Figure 5 - photograph by Tom Bullock (reproduced with permission of The Megalithic Portal: http://www.megalithic.co.uk/article.php?sid=1351410451)

Dudley believes that this is "without doubt the most perfect specimen of an Old Stone Age barrow in Europe" (Edwards 1981: 211). Even to Ebenezer's non-specialist eye the stones look newer rather than older than those at L'Islet. La Société Guernesiaise can't make up its mind and would like to see some bones from the site that could be dated more accurately. La Société Jersiaise, typically, believes the whole site is a fake.

In the final episode of this story, one of Ebenezer's young relations, playing at the site, does dig up some strange bones, bearing unusual marks and designs. Dudley leaps to the conclusion that they are the bones of an extinct "woolly rhinoceros" (Edwards, 1981: 219). Ebenezer is again sceptical, although he is charmed by the thought of such an animal wandering across L'Ancresse Common, which has been converted in recent years into a golf course. When the bones are sent off to specialists in England for analysis, their opinion is that they are the bones of a prehistoric red deer and bear marks on the jawbone made by people of the New, not the Old, Stone Age. Although this sequence of events is composed for comic effect, largely at the expense of Dudley Waine, it's not an inaccurate 
picture of the progress of archaeology on the islands. Some details show that Edwards kept his eye on the detail of real events, even from the distance of his long exile in England. Johnson cites the case of bones found on Jersey in 1939 that were revealed as belonging to a new, but extinct race of deer (Johnson 1981: 7). After the war, the site is added to the list of Ancient Monuments and Ebenezer is given the job of looking after it: "So in my old age, I became a worker for the States [the island government]. I never thought I would sink so low" (Edwards, 1982: 220).

Dudley was not really that wide of the mark, but he's bitterly disappointed that he cannot prove that the monuments on Guernsey are older than Jersey's. In disgust, he turns away from archaeology towards stories of Guernsey's supernatural, and when he visits the island again after the War he has developed a bizarre theory that the patois of Guernsey was originally a medium of communication between witches and fairies. Johnson's Golden Age of Archaeology in the Channel Islands ended with the coming of the Second World War, which dried up all the funding for research, and the post-War building boom that physically compromised so many sites. But it was also undermined by a new Age of Druidry and interest in the occult as well. Johnson recounts the privately sponsored 'reexcavation' and reconstruction of the passage grave at Le Déhus in 1932-33 by a specialist in the occult. Ronald Hutton has commented of Stonehenge, although it could be applied to any megalithic site in Britain: "it was a great... irony that modern Druids had arrived at Stonehenge just as archaeologists were evicting the ancient Druids from it" (Hutton, 2009: 323).

\section{BIBLIOGRAPHY:}

De Garis, M (1975) Folklore of Guernsey, Channel Islands: Guernsey Press

Edwards, GB (1981) The Book of Ebenezer Le Page, New York: Alfred A. Knopf

Falle, P (1734) Caesarea: Or, an Account of Jersey, the Greatest of the Islands Remaining to the Crown of England of the Ancient Dutchy of Normandy (2nd edition), London: T. Wotton

Hibbs, JL (1986), 'Post depositional transforms and the megalithic distributions of the Channel Islands', in Johnston, P (ed) The Archaeology of the Channel Islands, Chichester: Phillimore: 207-24

Hugo, V (1866) Les Travailleurs de la mer, Paris: Nelson, 1866 (Translated by Moy, W Thomas and published as Toilers of the Sea, London: Dent, 1911)

Hutton, R (2007) The Druids, London: Hambledon Continuum

Hutton, R (2009) Blood and Mistletoe, New Haven: Yale University Press

Jelly, K (2016), 'Reviewing the Megaliths of Northern Guernsey', in Nash, G and Townsend, A (eds), Decoding Neolithic and Mediterranean Island Ritual, Oxford and Philadelphia: Oxbow, Kindle edition

Jennings, G and Marquis, Y (ed) (2011) The Toad and the Donkey: An Anthology of Norman Literature from the Channel Islands, London: Francis Boutle 


\section{Goodall: Revealing Guernsey's Ancient History}

Johnson, D (1981) The Channel Islands: An Archaeological Guide, Chichester: Phillimore

Kendrick, T and Hawkes, J $(1928,1939)$ The Archaeology of the Channel Islands (v1, The Bailiwick of Guernsey, by Kendrick, T and v2, The Bailiwick of Jersey, by Hawkes, J), London: Methuen

Kinnes, I (1982) 'Les Fouaillages and megalithic origins', Antiquity v56: 24-30

Lenfestey, G (2011) 'George Métivier: A Reappraisal', Reports and Transactions of La Société Guernesiaise for 2010 v26 n5: 699-719

Lubbock, J (1890) Prehistoric Times, as Illustrated by Ancient Remains, and the Manners and Customs of Modern Savages (5th edition), London and Edinburgh: Williams and Norgate

Lyell, C (1997) Principles of Geology, Secord, JA (ed), London: Penguin

Marett, RR (1941) A Jerseyman at Oxford, London: Oxford University Press

Patton, P (1995) Neolithic Communities of the Channel Islands, BAR British Series 240, Oxford: Tempvs Reparatvm

Sebire, H (2007) From Antiquary to Archaeologist: Frederick Corbin Lukis of Guernsey, Newcastle: Cambridge Scholars

Sunbright57 (2012) The Journal of Antiquities, 'La Gran'Mere Du Chimquiere, St Martin, Guernsey, Channel Islands', http://thejournalofantiquities.com/2012/o9/o4/la-gran-meredu-chimquiere-st-martin-guernsey-channel-islands/ - accessed January 2016

Stukeley, W (1740) Stonehenge, a Temple Restor'd to the British Druids, London: W. Innes and R. Manby 